\title{
Künstliche und natürliche Intelligenz
}

\section{S. Frintrop}

Online publiziert: 14. März 2012

(C) Springer-Verlag 2012

Liebe Leserinnen und Leser,

seit September 2010 bin ich Mitherausgeberin der KIZeitschrift und möchte dieses Editorial nutzen, um mich Ihnen vorzustellen. Ich bin Akademische Rätin an der Universität Bonn und beschäftige mich mit kognitiver Bildverarbeitung für mobile Systeme.

Zurzeit beschäftigt mich allerdings die natürliche Intelligenz stärker als die künstliche:

Vor 9 Wochen ist meine Tochter zur Welt gekommen, und während ich dieses Editorial schreibe, verfolgt sie eifrig das Mobile über ihrer Wiege mit den Augen. Ihr großer Bruder ist zwei Jahre älter und erkundet mit allen möglichen und unmöglichen Mitteln die Welt.

Und wie den meisten KI-lern, die Kinder bekommen, drängt sich auch mir die Frage auf, wie eigentlich heutige KI-Systeme im Vergleich zu Kleinkindern abschneiden. Insbesondere die Robotik hat in den letzten zwei Jahrzehnten große Fortschritte gemacht: Roboter können Gegenstände in die Luft werfen und wieder auffangen, Treppen steigen, ja sogar tanzen. Sie können riesige Datenmengen analysieren, clustern, und nach Mustern durchsuchen, sie erzeugen detaillierte Karten ihrer Umgebung, detektieren Gesichter und erkennen Verkehrsschilder.

Aber trotzdem schneidet ein heutiger Roboter bei einem Vergleich mit einem Kindergartenkind in vielen Aspekten ziemlich schlecht ab. Wer schonmal ein Kind auf einem Spielplatz beobachtet hat, wie es z.B. beliebige Klettergerüste erklimmt, die es nie zuvor gesehen hat, und mit ande-

\section{S. Frintrop ( $\square)$}

Institut für Informatik III, Rheinische

Friedrich-Wilhelms-Universität Bonn, Römerstr. 164,

53117 Bonn, Deutschland

e-mail: frintrop@iai.uni-bonn.de ren Kindern interagiert, und ebenso einen Roboter bei einem der bekannten Roboter-Challenges wie z.B. RoboCup Soccer, RoboCup Rescue oder RoboCup@ Home, der weiß was ich meine. Vielleicht noch deutlicher wird der Unterschied im Bereich Bildverarbeitung: Letztes Jahr z.B. hat das beste Computer Vision System im Forschungswettbewerb PASCAL VOC 2011 Challenge, bei der Aufgabe, Topfpflanzen in Bildern zu detektieren, nur eine Genauigkeit von 16.2\% erreicht. Und in der letzten Semantic Robot Vision Challenge wurden vom besten System gerade mal 13 von 20 Alltagsgegenständen erfolgreich erkannt. Wie die Erkennungsrate von Babys für Topfpflanzen ist, ist meines Wissens nach noch nicht untersucht worden, aber bereits 6-9 Monate alte Babys sind in der Lage, Tiere von Möbeln zu unterscheiden.

Computer haben natürlich andere Bereiche, wo sie Menschen problemlos übertreffen; jeder von uns kennt sie. Aber wie kommt es, dass die Basisfähigkeiten des Menschen Bewegung, Perzeption, Lernen - so schwer zu simulieren sind? Eine Antwort ist sicherlich, dass die Evolution Jahrtausende Zeit hatte, uns für unsere Umgebung und Aufgaben zu optimieren. Interessanter für die KI ist aber vielleicht die Frage, was können wir von der Natur lernen, um unsere Systeme zu verbessern? Welche Konzepte ermöglichen Menschen, die enorme Datenflut zu bewältigen und mit neuen, unbekannten Situationen fertig zu werden?

Diese gehören zu den wesentlichen Fragen, die mich in meiner Forschung antreiben, und zwar insbesondere in den Bereichen Bildverarbeitung und Robotik. Hierbei finde ich einerseits interessant, wie mithilfe kognitiver Konzepte bessere Lösungen für KI-Standardprobleme gefunden werden können. Andererseits ist es auch so, dass Roboter, die nach menschlichem Vorbild konzipiert sind, auch für Menschen intuitiver und nachvollziehbarer agieren. Dies vereinfacht die Mensch-Roboter Interaktion beträchtlich, insbesondere 
wenn Roboter nicht mit Experten, sondern mit Laien interagieren sollen.

Eine vereinfachte Interaktion von Mensch und Maschine zu erreichen, ist auch ein wesentlicher Aspekt dieses Schwerpunktheftes. Ich habe dieses Heft als Patin mitbetreut, was mir viel Spaß gemacht hat. Ich möchte mich bei dem Gastherausgeber Achim Ebert für die gute Zusammenarbeit bedanken, und übergebe hiermit an ihn und das Thema Human-Computer-Interaction.

Viel Spaß beim Lesen,

Simone Frintrop

\section{Planned Main Topics}

\section{Spatiotemporal Modeling and Analysis}

Spatiotemporal data describe phenomena and movements of objects as they take place over time and space. Due to the availability of affordable monitoring technologies (e.g., sensor nodes, GPS, RFID) and the enormous amounts of data produced by them, AI research on the analysis and modeling of spatiotemporal data has enormously grown in importance over the last decade. Novel applications, from activity recognition to route prediction, have posed new challenges for both the modeling paradigms and analysis algorithms, along with specific questions such as the handling of noise and missing data, real-time evaluation in possibly distributed systems, complexity reduction for interactive analysis, displaying of results, and the protection of sensitive, private information.

This special issue of the Künstliche Intelligenz journal presents a forum for articles on current research activities and developments of spatiotemporal modeling and data analysis. The topics of interest include but are not limited to:

- algorithms and models for spatiotemporal data,

- sensor networks and distributed systems,

- agent-based simulation of moving objects,

- visual analytics, and

- privacy preserving data mining and analysis methods.

In addition to technical research papers, this special issue will accept project and dissertation reports as well as discussion and market reports in order to provide a comprehensive overview of current activities in this area.

Interested authors are asked to contact the guest editors of this issue as soon as possible:
Christine Körner

Fraunhofer IAIS

Schloss Birlinghoven

53754 Sankt Augustin

Email: christine.koerner@iais.fraunhofer.de

Prof. Dr. Stefan Wrobel

Fraunhofer IAIS und Univ. Bonn

Schloss Birlinghoven

53754 Sankt Augustin

Email: stefan.wrobel@iais.fraunhofer.de

Dr. Michael May

Fraunhofer IAIS

Schloss Birlinghoven

53754 Sankt Augustin

Email:michael.may@iais.fraunhofer.de

\section{Neural Learning Paradigms}

The capability of the human brain constitutes an ever fascinating topic, and a major goal of Artificial Intelligence is to mimic these capabilities. Unlike 'classical AI', Neural Computation directly uses learning paradigms inspired by human brains to arrive at intelligent behavior. Its great success story dates back more than 20 years with the introduction of efficient brain-inspired learning algorithms such as back-propagation, Hopfield-networks, or self-organizing principles. Since then, Neural Computation became a well established research area, and numerous brain-inspired techniques offer standard learning algorithms in today's digital data processing. In parts, Neural Learning Paradigms are already so commonplace that they are considered just another method of statistical data analysis. Modern information science is about to change this situation: an ever increasing complexity of data and learning tasks poses new challenges on the learning paradigms such as efficiency, flexibility, and robustness, when dealing with large data volumes, and scaffolding, self-organization, and emergence of structures when dealing with complex learning scenarios.

This special issue includes technical papers, reports on current research projects, interviews, book reviews and others with focus on current developments and challenges in Neural Learning Paradigms.

Topics of interest include but are not limited to:

- neural learning paradigms for complex data structures and structure inference

- self-organizing principles

- sparse coding and compressed sensing

- reservoir computing

- deep learning 
- neural inspired learning techniques for brain computer interfaces

- autonomous learning systems

- challenging applications of neural learning paradigms

Interested authors should contact the guest editor as soon as possible:

\section{Prof. Dr. Barbara Hammer}

CITEC Centre of Excellence

Bielefeld University

D-33594 Bielefeld

bhammer@techfak.uni-bielefeld.de

\section{Symbol Grounding}

In robotics and intelligent systems, there is a growing trend to include high level semantic knowledge for enabling better reasoning and increased functionality. One of the most important aspects in integrating is the problem of intrinsically linking the symbols used by a cognitive agent to their corresponding meanings through grounding language in perception and action. This is widely known as the "Symbol Grounding Problem (SGP)" defined by Harnad in 1990, where a linguistic symbol representing a meaning, needs to be grounded in the perceived world. For cognitive agents and robots, a subset of symbol grounding is the anchoring problem which focuses on the connection between symbols and physical object while interacting in the environment. In a multi-robot system, this problem is more challenging as symbols have not only to be grounded, but commonly shared in order to facilitate the exchange of information. This is called the social grounding problem. This also raises questions with respect to human-robot dialog modeling, where symbols and their references need to be communicated and how the social grounding between robots can be made transparent to a human interaction partner.

This special issue includes technical papers, reports on current research projects, interviews, book reviews and others with focus on current developments and challenges in Symbol Grounding in intelligent systems.

Topics of interest include but are not limited to:

- Symbol Grounding in intelligent systems

- Social Symbol grounding

- Anchoring symbols to sensor data form physical objects

- Symbol Grounding applied to language acquisition

- Symbol Grounding in robotics and intelligent systems

- AI applications of Symbol Grounding

- Knowledge representation and reasoning for robotics and intelligent systems

- Dialog modeling and Symbol Grounding Interested authors should contact one of the guest editors to discuss a possible contribution:

\section{Prof. Silvia Coradeschi}

AASS, Örebro University

SE70182 Örebro, Sweden

silvia.coradeschi@oru.se

\section{Docent Amy Loutfi}

AASS, Örebro University SE70182 Örebro, Sweden amy.loutfi@oru.se

Dr.-Ing. Britta Wrede

CoR-Lab/Applied Informatics

Bielefeld University

bwrede@techfak.uni-bielefeld.de 